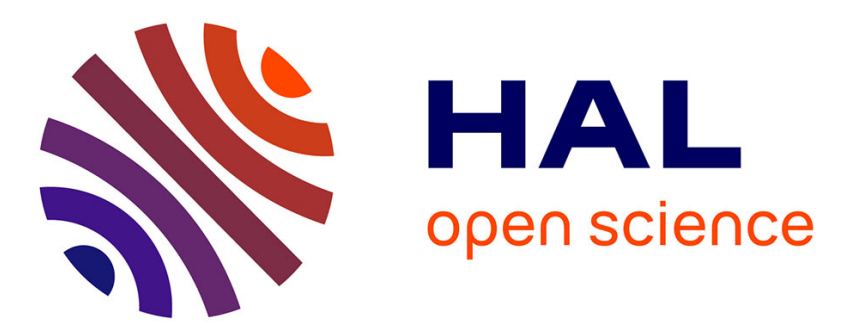

\title{
Turning scientific and technological human capital into economic capital: the experience of biotech start-ups in France
}

David Catherine, Frédéric Corolleur, Myriam Carrère, Vincent Mangematin

\section{- To cite this version:}

David Catherine, Frédéric Corolleur, Myriam Carrère, Vincent Mangematin. Turning scientific and technological human capital into economic capital: the experience of biotech start-ups in France. Research Policy, 2004, 33 (4), pp.631-642. 10.1016/j.respol.2004.01.009 . hal-00422583

\section{HAL Id: hal-00422583 \\ http://hal.grenoble-em.com/hal-00422583}

Submitted on 16 Oct 2009

HAL is a multi-disciplinary open access archive for the deposit and dissemination of scientific research documents, whether they are published or not. The documents may come from teaching and research institutions in France or abroad, or from public or private research centers.
L'archive ouverte pluridisciplinaire HAL, est destinée au dépôt et à la diffusion de documents scientifiques de niveau recherche, publiés ou non, émanant des établissements d'enseignement et de recherche français ou étrangers, des laboratoires publics ou privés. 


\title{
TURNING SCIENTIFIC KNOWLEDGE INTO \\ CAPITAL: THE EXPERIENCE OF BIOTECH START-UPS IN FRANCE
}

\author{
Catherine D., F. Corolleur, M. Carrere and V. Mangematin* \\ UMR GAEL, INRA, Université Pierre-Mendès-France, BP47 38040 Grenoble Cedex 9 France
}

\begin{abstract}
This paper examines how Scientific and technological (S\&T) human capital is transformed into financial capital through the creation of firms by scientists. The study is based on the analysis of the role and position of the 132 founders of 62 French biotech SMEs in their early years. .

Our empirical analysis highlights that scientists who have the highest human capital in terms of reputation and scientific visibility (estimated through academic status and publications) play a similar part to investors in financial capital. They bring scientific results as a capital and have a strategic and scientific advisory role. However, they are only partially involved in the firm as they retain their position in academia. By contrast, less famous scientists cannot valorise a stock of human capital, only a potential. To transform potential into stock, they involve themselves completely in the firm in a managerial position. The creation of the start-up is based on the transformation of a scientific result in innovation. They found a firm with a weak growth potential and have to generate cash flows to finance their development and even their survival.
\end{abstract}

JEL Classification: O32, M13, J24

Keywords: Biotechnology, SMEs, Scientist, Founder, Technological transfer, human capital

The authors acknowledge financial support from the Commissariat general au Plan.

* Corresponding author. 


\section{Introduction}

The aim of this paper is to analyse how scientists transform their scientific and technological (S\&T) human capital into financial capital through the creation of start-up companies. Previous research has either studied the linkages between start-ups' performance and the composition of their founder networks (Baum et al., 2000) while Shane and Stuart (Shane et al., 2002) focus on the influence of entrepreneurs' resources on the life expectancy of the firm. Both of these sets of research focus on firm performances. Other research focuses on the mechanisms for transferring technology: technological spill over (Cohen et al., 2002) from the public sector research on industrial $R \& D$ and the pathways through which the effects are excised (Mowery et al., 2001); impacts of public sector research on firm creation (Autant-Bernard et al., 2002; Colyvas et al., 2002; Swann et al., 1999).

This paper benefits from these results. It focuses on the individual strategies to make money by commercialising science via firm creation. Technology transfer through human capital mobility has been recently investigated. It includes hiring of trained researchers to develop a specific research programme or technology (Almeida et al., 1999) as well as firm creation by scientists (Zucker et al., 1998). S\&T human capital is defined as the sum of scientific and technical and social knowledge, skills and resources embodied in a particular individual (Bozeman et al., 2001)

Scientists tend to engage in research because they enjoy the challenge. They are also careful about their reputation and sometimes try to valorise their discoveries. Public policies in favour of commercialisation of science (Bayh-Dole act in 1980 in US, Loi Allègre in France in 1999) as well as the emergence of new opportunities based on knowledge-based industries has led to a new wave of firm creation by scientists. Recent years have seen 
experiments by star scientists (Stephan, 1999; Zucker et al., 1999) as well as those less well known in firm creation (Mangematin et al., 2003). Success stories of star scientists who found fast growing star-up like Greg Venter have been emphasised. Meanwhile, other scientists are creating small firms which remain small. Different pathways to valorise S\&T human capital through firm creation seem to exist. Do scientists with different levels of S\&T human capital set-up different kinds of firms? Do they occupy different positions within the firm (Chief Executive Officer, scientific advisors, etc.)? Do their positions in the public sector research (tenure, non tenure, diploma and experience) influence the pathway by which they valorise their S\&T human capital? In Section 3 we examine the cases of 132 founders who created 62 New Biotechnological Firms (NBF) in France. Human capital is estimated by initial training, position in academia and on-the-job training (experience). Returns on human capital are estimated by the position within the firm. Section 4 discusses the determinants of two individual trajectories according to the renown of the scientists, to their position in academia and to their involvement in firms.

\section{The role of human resource mobility in technology transfer in state-of-the-art technologies}

Biotechnology is a new industry that is knowledge-based and predominantly composed of new small firms that have close ties with university-based scientists. These start-ups play a particular role in industrial organization as they provide a link between large firms and academic organisations. Scientific and technological production requires a circulation of knowledge (Winter, 1987). Leonard-Barton argues that knowledge transfer requires various mechanisms of communication such as the transfer of people when the level of codifiability is low. The more knowledge is tacit, the greater the variety of modes of transfer: articles, patents, and also temporary or permanent personal mobility, joint ventures, etc. 
(Mangematin et al., 1999). Because tacit knowledge is embodied in individuals, it is more likely to be diffused within the organization than outside of it. Almeida et al. (Almeida et al., 2002) show that multinational firms transfer knowledge across countries more effectively than alliances because they are able to mobilise key persons. Even within the firm, tacit knowledge is sticky and does not flow easily unless the individuals possessing it also move (Szulanski et al., 2001). When knowledge is difficult to separate from those who produce and possess it, because it is tacit, hiring people from other organizations is a way of transferring otherwise immobile knowledge. The phenomenon of post doctoral illustrates the importance of human mobility in circulating knowledge. It is a way for young scientists to acquire specific tacit knowledge and know-how developed in a given organization. Hiring skilled people is also a way for an organisation to acquire critical knowledge. The mobility of experienced scientists not only provides a one-time technology transfer of information, as is often the case in technology licensing; it also facilitates the transfer of competencies, permitting further knowledge building (Kim, 1997), especially because experienced people bring their own networks into the firm.

Knowledge transfer between universities and firms occurs when university-based scientists found a firm with the explicit goal of developing knowledge created in their university lab. From an individual point of view, the decision to become an entrepreneur is generally considered in human capital models as a means to gain a higher income than could be attained as an employee (Campbell, 1992) ${ }^{2}$. Douglas and Shepherd study (Douglas et al., 2002) emphasizes that the intention to be an entrepreneur is stronger for those with more positive attitudes to risk and independence. The process means that university-based scientists play different roles. When university-based scientists physically move from

\footnotetext{
${ }^{2} \mathrm{He} / \mathrm{sh}$ e evaluates whether there are positive expected net present benefits of entrepreneurship relative to the expected gains from labour wage (Campbell, 1992).
} 
academic laboratories to their start-ups, they usually play a leading role within the start-up, as CEO (Chief Executive Officer) or as a board director (usually research director). However, partial or temporary mobility does exist. Founders can go back to academia after the founding stage or they can keep a part time position in academia. In that case, they serve as scientific advisers or part-time scientific directors within the start-up.

The role that university-based scientists play varies according their position in academia and their renown. Those who are faculty members, such as tenured scientists, may transfer technology and knowledge for a short period of time by founding a start-up and then return to academia. Those who were hired on soft (contract money for example) money in academia (post docs, contract researchers, etc.) may found a firm to create their own jobs. They will then stay within the firm after the founding phase. When Audretsch and Stephan (Audretsch et al., 1999) compare academic founders and founders from industry, they focus on the ability of scientists to appropriate the value of knowledge embedded in their human capital along with the incentive structure influencing if and how scientists choose to commercialise their knowledge. They find that academic founders are older and more eminent - in term of citations - than those from industry. Academic founders held part-time positions within the firms - as consultants or members of the scientific advisory board while those scientists whose careers had been entirely spent working in industry held fulltime positions. These remarks lead to two related hypotheses:

P1: Amongst University-based scientists involved in startup creation, scientists with a high level of academic production have a part time position in the firm as scientific advisor. 


\section{P2: Non-university-based scientists or non-tenured scientists have a position as CEO or in the top management.}

The roles of university-based scientists may differ according their own scientific background and professional trajectories. One of the consequences of these different trajectories is different type of start-ups. Studies on the development of new biotech firms (NBF) have focused on a business model, in which entrepreneurs rely on growth forecasts to persuade capital investors (business angels and venture capitalists) to invest in a radical innovation project. Firms aim for a world market to commercialise their innovation, and an initial public offering (IPO) enables initial investors to make profits that offset their risky initial investment. But not all firms aim to be listed on the stock exchange. Some firms are not designed to experience exponential growth, and choose to target local markets (Mangematin et al., 2003). One can expect that a scientist who has a permanent position in academia and a part-time position in a start-up may be involved in a riskier firm than a less famous or nontenured scientist who relies solely on his or her position in a start-up. However famous (star) scientists are supposed to realize breakthrough innovations and to derive economic value from their research. They are involved mostly in the pharmaceutical sector, in the development of new drugs or therapeutics. Such innovations may generate huge revenues if successful, but they are risky. Long and costly developments are required before cash flow is generated. To finance their activities, such firms have to convince venture capitalists to invest and large pharmaceutical firms to develop contact research. The scientific visibility of academics involved in the start-up is itself a stamp of quality: it increases the firm's scientific credibility and its ability to attract funding. On the other hand, less famous scientists create firms based on incremental innovations such as the promising results of their $\mathrm{PhD}$ or post doctoral work. Most of these firms are not able to attract business angels 
or venture capitalists. They thus have to generate cash flows from their day-to-day business, like a traditional firm. Thus hypothesis $\mathrm{H} 3$ can be designed:

\section{P3: The more experienced and productive scientists create riskier firms.}

\section{Data and methods}

To analyse the ways by which founders ${ }^{3}$ valorise their human capital by founding start-ups, two sets of data are required: information on firms and their initial performance, and information on individuals, mainly their CVs and their function in firms. While Stephan and Everhart (1998) focus only on firms in the IPO process, we study a broader sample. Firms in the IPO process or already listed have specific characteristics: created by star scientists, they are mainly involved in bio-pharmaceuticals. To study the variety of situations of technology transfer when scientists are founding a start-up it is necessary to have a sample of different business models, including both those that are able to make an IPO and those that remain small. In our study data were collected on a sample of 132 founders of 62 new French biotech firms. The 62 firms were selected through the biotech data of the Ministry of $\operatorname{Research}^{4}$ (http://biotech.education.fr), which describes 200 independent biotech firms in 20015. Our sample of 62 firms covers a variety of types with different trajectories (increase of turnover, exponential growth, stagnation, regression) in different regions. Legal data (year of creation, founders, board of trustees, board of directors) and financial data (turnover, employees, benefits, etc.) were collected through the website http://www.societe.com. Both

\footnotetext{
${ }^{3}$ Following the work of Gartner et al. (1994), we defined founders as physical persons who invest in the firm from the outset and who participate in the definition of its initial strategy.

4 This database describes all French biotech firms as well as incubators, venture capitalists involved in biotech and other actors linked to biotech.

5 Estimations about the total number of biotech SMEs in France are converging around 200 Ernst\&Young. 2001. Life Sciences in France - 2001- Where creativity meets business. Ernst Young International.: Paris .
} 
websites allow us to identify most of the founders involved in the firm's creation. These data were completed and checked through short interviews with the founders.

Data on founders covers five different areas: personal characteristics (gender and age) initial training i.e. highest diploma or grade, professional experience (scientific or managerial, in academia or in industry), status at the set-up of the firm (student, faculty member, employee) and position within the firm 5 years after the creation (Executive or advisory position).

The founders' initial training represents the start-up's basic human capital. Additional competencies and know-how are captured by analysing careers and professional trajectories.

Inspired by Audretsch and Stephan's work on professional trajectories of scientists (Audretsch et al., 1999) and on that of Dietz et al. on CVs (Dietz et al., 2000), we collected the CVs of founders. Founders' professional careers generate different forms of learning, both scientific and managerial. We coded professional experience of all founders in four variables:

i) Scientific experience in academia (EXPSCACA) corresponds to faculty member, i.e. a position of assistant or associate professor, professor, researcher or director of research in a public research institute or university. People hired in soft (?) money areas like post-doc, $\mathrm{PhD}$ candidate and research engineer are not included in this variable.

ii) Scientific experience in industry (EXPSCIND) corresponds to a position of chief scientific officer, director of clinical tests, etc... in industry.

iii) Managerial experience (EXPMNGT) corresponds to a position of top manager in any private firm (marketing, business development, financial, commercial, operating or general director exclude of scientific director. 
iv) Experience of serial founder (SERIALFD) describes founders who create several biotech start-ups. ${ }^{6}$

Finally, as the aim of the paper is to analyse how founders valorise their human capital and skills within firms, the positions they occupy after the founding are described (VALOPOST variable). We chose to record their positions five years after the firm creation. For those firms that did not last five years (6 firms), we keep the positions in 2002. We distinguish between Executive positions such as Chief Executive Officer ${ }^{7}$ (CEO) and Top management $(\mathrm{MNGT})^{8}$ which generate salaries (and dividends if the CEO is a shareholder), and advisory positions such as member of the board of trustees (BT) and scientific board (SAB). Put another way, a founder who occupies an executive position is employed by the firm, while one in an advisory position is only employed part-time for advice and consultancy. First, we detect founders who occupied CEO position. Next, Top Management (except CEO) and SAB positions are also detected. One founder never cumulates these three positions. Last, the position within board of trustees is identified but only for founders who do not occupy one of the above positions ${ }^{9}$.

Table 1 presents the main characteristics of the founders; personal characteristics (age at creation and gender), initial training ( $\mathrm{PhD}$ in sciences, $\mathrm{MSc}$ or $\mathrm{MBA}$ ), professional experience (in academia or industry), position before creation and, finally, position within the firm. The founders in our sample are mainly male $(92,4 \%)$ and 41 years old at the time

\footnotetext{
6 Each independent variable is binary, YES and NO. For each variable the total is equal to 132 (the number of founders).

${ }^{7}$ In all English-speaking countries the functions of execution (CEO) are distinguished from those of control (Chairman of the Board of Directors). In France these functions can be cumulated in the position of PDG (President Directeur Général). Our variable CEO encompasses chairman of the board, managing director and manager.

${ }^{8}$ Corresponding mainly to a position of financial, marketing, business development or scientific director, but except CEO.

${ }^{9}$ We observe that some founders cumulate a position within the board of trustees with another one (CEO, Top Management or Scientific Board).
} 
of the firm's creation. More than half of them are between 30 and 45 years old $(62 \%)^{10}$. Junior founders (under 30 years old) do exist (16\%) in the sample. They create the firm directly after their $\mathrm{PhD}$ or post doctorate. ${ }^{11}$ The highest academic qualification defines the initial training of the founder. Regarding scientific training, most founders have a $\mathrm{PhD}$ $(75 \%)$ in life sciences, sometimes in addition to a degree in medicine or pharmacy. ${ }^{12}$ Some $18 \%$ of the founders have a master's degree in management. In fact, some of the founders have both degrees, in management and sciences. All together, the average length of initial training is 7.15 years at university, which is more than in other high tech sectors (NTIC Start up APCE, 1999). Some $43 \%$ of the founders have a scientific experience in academia. The number of publications (Deeds et al., 1999) is a proxy for scientific visibility: 53 academic founders published 16 articles on average between 1989 and 2001 (Source: Biotechnology Citations Index.). In the sample, 58 founders had previously occupied a director 's position in a private sector ( 20 with a scientific function and 38 with a management function). Out of those 38, 5 were involved in financial functions within venture capitalists or banks, before founding the start-up. Some 22 founders, including 13 with high experience in academia, had already created a firm before founding the firm under review.

10 Academic founders are 54 years old in Zucker et al. Zucker LG, Darby MR, Armstrong J. 2002. Commercializing Knowledge: University Science, Knowledge Capture, And Firm Performance in Biotechnology. Management Science 48(1): 138-153 sample based on start-ups, which have done an IPO and 47 years old in Audretsch and Stephan's sample (1999).

11 These proportions are similar to those in the NTIC industry as pointed out by the study of the Agence pour la Création d'Entreprise concerning 84 French start-ups founded between 1995 and 1999, especially in the NTIC sector. Their founders' main characteristics were as follows: $97 \%$ men; $17 \%$ under the age of 30 and $58.5 \%$ between 30 and 45; at least a four-year university degree (APCE, 1999).

12 Note also that $13 \%$ of the founders have a master's degree in engineering, in life sciences or in chemistry or physics. Thus, $88 \%$ of the founders have at least a master of sciences. 
Table 1: Characteristics of founders

\begin{tabular}{|c|c|c|c|c|}
\hline Variables & Description & Modalities & $\#$ & $\%$ \\
\hline \multicolumn{5}{|c|}{ Personal characteristics } \\
\hline GENDER & Dichotomous & $\begin{array}{l}\text { Female } \\
\text { Male }\end{array}$ & \begin{tabular}{|l|}
10 \\
122
\end{tabular} & $\begin{array}{l}7.5 \\
92.5\end{array}$ \\
\hline AGECREATION & Continuous. Age when the firm is created & & $41(10)$ & \\
\hline \multicolumn{5}{|l|}{ Initial training } \\
\hline TRAINING & Initial training of the founder & $\begin{array}{l}\text { PhD in sciences } \\
\text { Master of Business Administration } \\
\text { Master of sciences and MBA } \\
\text { Less than master's }\end{array}$ & \begin{tabular}{|l|}
93 \\
16 \\
6 \\
17 \\
\end{tabular} & $\begin{array}{l}70.5 \\
12.0 \\
4.5 \\
13.0\end{array}$ \\
\hline \multicolumn{5}{|c|}{ Professional experience } \\
\hline EXPMNGT & Experience in management in firm & $\begin{array}{l}\text { YES } \\
\text { NO }\end{array}$ & \begin{tabular}{|l|}
38 \\
94
\end{tabular} & $\begin{array}{l}29.0 \\
71.0\end{array}$ \\
\hline EXPSCACA & Scientific experience in academia & $\begin{array}{l}\text { YES } \\
\text { NO }\end{array}$ & $\begin{array}{l}57 \\
75\end{array}$ & $\begin{array}{l}43.0 \\
57.0\end{array}$ \\
\hline EXPSCIND & Scientific experience in industry & $\begin{array}{l}\text { YES. } \\
\text { NO }\end{array}$ & $\begin{array}{l}112 \\
20\end{array}$ & $\begin{array}{l}85.0 \\
15.0\end{array}$ \\
\hline SERIALFD & Previous experience as a founder & $\begin{array}{l}\mathrm{NO} \\
\mathrm{YES}\end{array}$ & $\begin{array}{ll}110 \\
22 \\
\end{array}$ & $\begin{array}{l}83.0 \\
17.0 \\
\end{array}$ \\
\hline \multicolumn{5}{|c|}{ Position before creation } \\
\hline STATUS & Status before the creation & $\begin{array}{l}\text { Student } \\
\text { Job in private sector } \\
\text { Job in academia } \\
\text { Serial founder }\end{array}$ & $\begin{array}{l}16 \\
25 \\
70 \\
22 \\
\end{array}$ & $\begin{array}{l}12.0 \\
19.0 \\
53.0 \\
16.0\end{array}$ \\
\hline \multicolumn{5}{|c|}{ Position within the firm } \\
\hline \multirow[t]{2}{*}{ VALOPOST } & Executive & $\begin{array}{l}\text { CEO } \\
\text { MNGT }\end{array}$ & $\begin{array}{l}56 \\
42\end{array}$ & $\begin{array}{l}42.0 \\
32.0\end{array}$ \\
\hline & Advisory & $\begin{array}{l}\text { SAB - Scientific board } \\
\text { BT -Board of trustees }\end{array}$ & $\begin{array}{l}20 \\
14\end{array}$ & $\begin{array}{l}15.0 \\
11.0\end{array}$ \\
\hline
\end{tabular}

The second set of data describes the start-ups. Only new science-based firms are analysed in this sample (Autio, 1995). ${ }^{13}$ Biotech SMEs are recent: most of the firms are less than ten years old on average and most are involved in the newest technologies (genomics and post genomics) (Lemarie et al., 2000). Biotech SMEs are active in a large variety of markets, i.e. human, animal and plant health, cosmetics, agriculture, agro-food and diagnostics. The firms are small in terms of employee numbers and turnover. Most of them are not profitable in the period studied. They are at the beginning of their life cycle and need large investments before generating enough turnover to cover running costs. They are science-based. On average, $R \& D$ expenditures account for over $66 \%$ of the turnover. These SMEs obviously belong to a high-tech sector. Some $76 \%$ of the founders have a scientific background and

13 Firms in the sample can be described as follows: (1) the business idea of the firms is essentially based on exploiting advanced technological knowledge developed or acquired in a source of technology; (2) each firm has been independent at least during its early years of existence; (3) each firm is entrepreneurial, that is, it is controlled and managed by an entrepreneur or by a group of entrepreneurs at least at the beginning; (4) their founders were affiliated with the source of technology before establishing the comp any. 
$14 \%$ are well-known scientists. 62 French Biotech SMEs each employs on average 33 people and generate $€ 3.2 \mathrm{~ms}$ of annual turnover. These values are consistent with the values of all 158 non-subsidiary French biotech firms 14 which compose the Ministry database (number of employees in average $=33$, turnover $=€ 3.7 \mathrm{~m}$ ). Otherwise, the size of the firm, measured in terms of turnover or number of employees, is not correlated with the date of creation. Turnover per employee is highly variable (between 0 and 0.5 million $€$ per person) and is not necessarily a good indicator of the firm's health. Promising firms may concentrate their initial efforts on technology developments and generate turnover only after several years.

In earlier works (Mangematin et al., 2003) we clearly identified two sub-groups with different levels of risk.

Table 2: General characteristics of the two sub-samples of firms

\begin{tabular}{|c|c|c|c|c|c|c|c|c|}
\hline & \multicolumn{4}{|c|}{$\overline{~ T r a d i t i o n a l ~ f i r m s ~(31 / 62) ~}$} & \multicolumn{4}{|c|}{ Risky firms (31/62) } \\
\hline & Average & Min. & Max. & Medium & Average & Min. & Max. & Medium \\
\hline Date of creation & 1990 & 1977 & 1998 & 1992 & 1994 & 1979 & 2000 & 1996 \\
\hline$\#$ of employees & 14 & 1 & 65 & 8 & 55 & 4 & 368 & 19 \\
\hline $\begin{array}{l}\text { R\&D expenditures } \\
(\mathrm{K} €)\end{array}$ & 175 & 0 & 899 & 61 & 4192 & 10 & 33061 & 1296 \\
\hline Turnover $(\mathrm{K} €)$ & 2094 & 35 & 16303 & 796 & 3554 & 0 & 24938 & 348 \\
\hline Net income $(\mathrm{K} €)$ & 58 & -1497 & 1756 & 17 & -1913 & -13975 & 1439 & -433 \\
\hline$\%$ of firms with VC & \multicolumn{4}{|c|}{$35 \%$} & \multicolumn{4}{|c|}{$77 \%$} \\
\hline
\end{tabular}

Table 2 presents the main characteristics of the two sub-samples of firms. Traditional firms generate sufficient cash flow (in average, positive net income $=58 \mathrm{~K} €$ ) to finance their current business, including research. In fact only one out of three such firms turns to venture capitalists (VC) to finance its development. By contrast, over two-thirds of risky firms rely on capital financing since the turnover generated by the firm is not enough to cover $R \& D$

\footnotetext{
14 In the total population of 200 French biotech firms, 44 are subsidiary companies.
} 
costs. The difference between the date of creation of risky and traditional firms is not significant. Empirically, the business model is described through the firm's initial project and the financing of the running activities during the first years of the firm. Does the firm need to run huge research programs before entering the market? (Criterion: size of the innovation project). If the firm develops a huge research program funded by external financing, it is said to be risky. If not, its level of risk is similar to other start-ups and not really specific to the biotech sector (Mangematin et al., 2003). The expected net value of a share of risky firm is supposed to be higher than traditional ones, it is the reason venture capitalists invest. The following section presents the econometric models and main results.

\section{Models and Empirical results}

Do university-based scientists valorise their human capital in a specific way compared with other founders? Does a high degree of human capital lead to specific ways of valorising it? Valorising scientific and human capital for a scientist means generating revenues (wages and capital) from his or her scientific results in addition to their salaries. Here, we only consider one mode of valorisation (firm creation) amongst other (patenting, consulting, etc.). To understand the determinant of the valorisation of human capital through the founding of a firm, we first analyse the position occupied by the founders after the creation of the firm. Four different logit models are performed to analyse the determinants of the founder position: the Scientific Advisory Board (SAB), the Chief Executive Officer (CEO), the board of trustees (BT) and positions in the top management (MNGT). Next, we evaluate the relationship between level of human capital and the level of risk of the firm. Logit models on three different variables have been performed. The logit model deals with qualitative variables. It analyses the influence of different modalities of qualitative variables on 
qualitative variables (Maddala, 1983). The paper presents two different analyses with two endogenous variables:

- Position of the founder in the firm: Scientific Advisory Board, Chief Executive Officer, Board of Trustees, and Management

- Type of firm: traditional or risky.

In order to exploit the data, and due to the size of the sample, we recode "training" variables and the variables describing the positions occupied by the founders, into several binomial variables. For each endogenous variable, binomial logit models were performed.

The models presented meet the following two conditions: overall relevance (we consider the Akaike criterion here as well as the likelihood ratio and score tests); and good predictive qualities (i.e. they must lead to a majority of well classified observations, a minority of badly qualified observations and a minority of ambiguous cases). Variables such as founder's status and age are not taken into account due to relations with other regressors ${ }^{15}$.

15 The indicators of relationship used are Cramer's coefficient for qualitative variables and the Pearson's correlation coefficient for quantitative variables. 
Table 3: Position of founder at least 2 years after the creation

\begin{tabular}{|c|c|c|c|c|c|c|}
\hline & \multicolumn{2}{|c|}{ Board of trustees } & \multicolumn{2}{|c|}{ CEO } & \multicolumn{2}{|c|}{$\begin{array}{c}\text { Scientific Advisory } \\
\text { Board }\end{array}$} \\
\hline & \begin{tabular}{|l|} 
Coefficient \\
(St. deviat)
\end{tabular} & Prob. & \begin{tabular}{|l|} 
Coefficient \\
(St. deviat)
\end{tabular} & Prob. & \begin{tabular}{|l|} 
Coefficient \\
(St deviat)
\end{tabular} & Prob. \\
\hline Intercept & $\begin{array}{r}-2.0320 \\
0.6004\end{array}$ & $\begin{array}{r}0.0007 \\
* * *\end{array}$ & $\begin{array}{l}0.5396 \\
0.3196\end{array}$ & $\begin{array}{r}0.0913 \\
*\end{array}$ & $\begin{array}{r}-3.4783 \\
0.6471\end{array}$ & $\begin{array}{r}.0001 \\
* * *\end{array}$ \\
\hline \multicolumn{7}{|l|}{ Initial training } \\
\hline PhD in Sciences & n.s. & & n.s & & n.s & \\
\hline MBA & $\begin{array}{l}0.7855 \\
0.4473\end{array}$ & $\begin{array}{r}0.0791 \\
*\end{array}$ & & & & \\
\hline Master of Sciences and MBA & n.s & & n.s & & n.s & \\
\hline \multicolumn{7}{|l|}{ Professional experience } \\
\hline Managerial experience & $\begin{array}{r}-0.6116 \\
0.5259\end{array}$ & 0.2448 & n.s & & $\begin{array}{r}-0.9205 \\
0.5370\end{array}$ & $\begin{array}{r}0.0865 \\
*\end{array}$ \\
\hline $\begin{array}{l}\text { Scientific experience in } \\
\text { academia }\end{array}$ & $\begin{array}{r}-1.2031 \\
0.5550\end{array}$ & $\begin{array}{r}0.0302 \\
* *\end{array}$ & & & & \\
\hline $\begin{array}{l}\text { Scientific experience in } \\
\text { industry }\end{array}$ & & & $\begin{array}{l}0.4876 \\
0.2681\end{array}$ & $\begin{array}{r}0.0690 \\
*\end{array}$ & & \\
\hline Publications & & & $\begin{array}{r}-0.5062 \\
0.1572\end{array}$ & $\begin{array}{r}0.0013 \\
* * *\end{array}$ & $\begin{array}{l}0.6576 \\
0.1828\end{array}$ & $\begin{array}{r}0.0003 \\
* * *\end{array}$ \\
\hline Serial founder & $\begin{array}{l}0.8295 \\
0.4670\end{array}$ & $\begin{array}{r}0.0757 \\
*\end{array}$ & & & & \\
\hline \multicolumn{7}{|l|}{ Personal characteristics } \\
\hline Gender & n.s & & n.s & & n.s & \\
\hline Likelihood ratio & $\begin{array}{r}\mathrm{DF}: 4 \\
\operatorname{Pr}: 0.003 \\
\end{array}$ & & $\begin{array}{r}\text { DF: } 2 \\
\text { Pr:0.001 }\end{array}$ & & $\begin{array}{r}\text { DF:2 } \\
\text { Pr:<.0001 } \\
\end{array}$ & \\
\hline \% Concordant & 72.00 & & 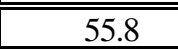 & & 75.1 & \\
\hline$\%$ Discordant & 11.6 & & 18.5 & & 12.9 & \\
\hline ( $* *$, if & 16.4 & & 25.6 & & 11.9 & \\
\hline
\end{tabular}

Table 3 calls for several comments. Professional experience constitutes the key variable for explaining the position occupied in the start-up. The variables that influence the position of the CEO are primarily experience in industry in a scientific position and number of publications, which play a negative role (models 3 and 4). Among the founders of a start-up, the person who will become CEO will be the one who transforms scientific advances into innovations and cash flows, that is, who has already tried out these skills in industry beforehand. Since researchers in industry publish less, the negative coefficient affecting publications is easily explained. To the position of CEO, the founders appoint the person with the required competencies to succeed in the business world. Economic valorisation of 
the human capital of university-based scientists is accomplished through partnerships with scientists familiar with the industrial world.

Hardly surprisingly, scientific visibility (number of publications) is the main determinant of participation on the scientific advisory board (model 6). Managerial experience acts negatively, signifying that founders who have managerial experience before set-up participate proportionally less on scientific boards. This observation confirms the results of Zucker et al. (Zucker et al., 1998) and of Stephan et al. (Stephan et al., 1998). Founders' participation on the scientific board often means that they are not or no longer employed by the firm but that they remain linked to its future. Out of the 132 founders whose function is clearly identified, only 33 are members of these boards, i.e. barely a quarter.

People who were involved in the creation of several firms are proportionally more numerous on boards of directors, while professional experience in academia or in management does not seem to be a determining factor (models 1 and 2). Presence on a board of trustees is also positively correlated with age. It often requires personal financial investment by the shareholder that only individuals who have accumulated enough financial capital can afford. This presence thus indicates an investment of direct financial capital and not the financial valorisation of human capital considered to be a contribution in kind. Note the excellent prescriptive quality in model 2 .

Neither the individuals' personal characteristics nor their initial training seem to play a decisive part in the position they occupy in the start-up. Only MBA graduates, who have often occupied or still occupy positions related to financing in business banks, to consultancy firms or to venture capitalists are proportionally more numerous on boards of directors.

Finally, the absence of the "top management" model is also significant. None of the exogenous variables selected - neither managerial experience nor managerial competencies 
- has a significant influence on the fact, for a founder, of being in the management of a startup.

On the whole, the two hypotheses are confirmed. Positions on scientific committees are occupied primarily by researchers with considerable scientific renown, related to the number of their publications. Consistent with the results of Stephan and Audretsch, (Stephan et al., 1998), these scientists are involved in firm creation part time and they keep their position in academia. In that case, academics serve as scientific advisers or consultants so as to facilitate and to renew knowledge circulation by providing links with other researchers. Together with the other founders, they provide the possibility of outsourcing research to university laboratories. They also provide the possibility of using academic equipment in the very early stages of the firm's life. Since the firm cannot afford to invest in costly and dedicated research equipment, the involvement of academics allows it to borrow or rent such facilities from the founders' lab. Technology transfer occurs at the very beginning when researchers found the firm. It is thus on a one-time transfer of a specific technology that the firm is built. This transfer also generates the conditions of a learning process through longterm cooperation between the founder's previous academic lab and the start-up. This includes the evaluation of research programs by being able to mobilize well-known scientists on the scientific advisory board; a signal to the scientific and financial community of the firm's quality via the involvement of highly visible scientists; and making the firm attractive to young and brilliant researchers who would like to join a company managed by well-known scientists.

These cases are, however, in the minority, as indicated. Founders who come from industry are involved essentially in the management of start-ups. Experience in academia has no significant effect for managerial position. The distribution of positions within start-ups is 
consistent with the founders' competencies. However many scientists, especially those who have not a high scientific visibility occupy managerial positions.

There is, however, another mode of valorisation of human capital through a total involvement in the firm. The stock of human capital is smaller than this of famous scientists and it is because it is being built up that people are involved in the firm. The founders try simultaneously to constitute a human and financial capital: the flow of human capital is accumulated through the experience acquired during the creation and management of the firm, and the firm pays wages for their qualified work. Valorisation of human capital differs, depending on the position occupied. But the mode of valorisation depends on the initial stock. A high level of stock requires less involvement by the founder and allows a direct conversion from S\&T human capital into financial capital, while less stock requires a continued generation of flows of S\&T human capital and thus the total involvement in the firm generates salaries.

Last, the question is whether the founders all create the same type of firm or whether the risk depends on the founders' initial human capital. Our sample consists of 31 so-called traditional firms and 31 riskier ones: 47 founders create traditional firms while 83 set up risky ones.

Table 4 analyses the determinants of the type of firm. 
Table 4: Determinants of the creation of risky firms versus traditional ones

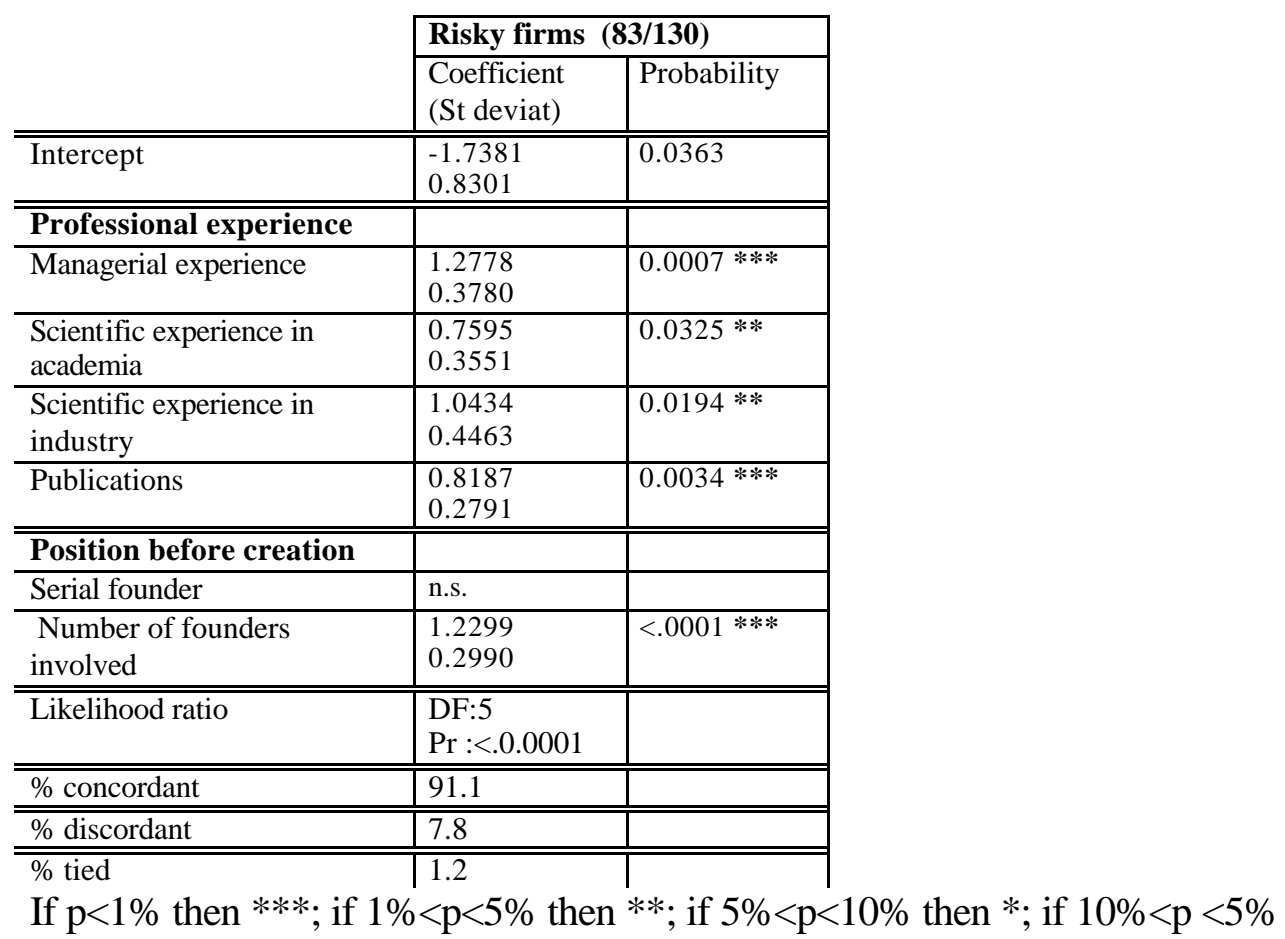

Only the experience variables are significant. They all vary in the same direction. The more experienced the founder, the more they create risky firms. Firms based on a radical innovation project are created by larger numbers of founders (the variable "number of founders" is significant and positive) who have additional competencies in management and scientific orientation. Hypothesis $\mathrm{H} 3$ is thus verified. It seems logical: the most experienced academics are in the best position to run radical innovation projects. To implement their projects they go into partnership with other scientists who have complementary experience in business and with professional managers. The scientists' reputation enables the firm to raise capital from investors and thus to finance its early years. The scientists' credibility also plays a key part. On the other hand, incremental innovation projects are run by less experienced scientists who rapidly have to provide products and services to finance day-today operations and thus generate cash flows to finance research and development. Growth expectations for each of the businesses models differ, as the massive presence of venture capitalists in the riskiest model attests. 


\section{Conclusion and discussion}

Our empirical analysis highlights two contrasting modes of valorisation of human capital: on the one hand, scientists who have the highest S\&T human capital in terms of reputation and scientific visibility (estimated through publications) play a similar part to investors in financial capital. They bring their S\&T human capital to the firm and have a strategic and scientific advisory role. They offer the firm access to an extensive scientific network and multiple contacts with industrial partners, as shown by the seminal study by Liebeskind, Oliver et al. (Liebeskind et al., 1996). Their reputation enhances the firm's credibility vis-àvis venture capitalists (Maurer, 2001). Famous academics involved in start-ups have effective S\&T human capital of several kinds: scientific competence, renown in the scientific community and beyond, and a large network of relations. Their savoir-faire enables them to bridge the academic and economic worlds, from which the start-up benefits. Their interest in scientific challenges and their scientific level prompts them to embark on the creation of new businesses that can have a major impact on the industry. They thus transform their S\&T human capital into financial capital (shareholding of high growth potential firms).

By contrast, less famous scientists cannot valorise a stock of S\&T human capital but they do have S\&T competencies and expertise. They use this potential to generate wages. Thus, they are involved in the firm in a managerial position. The creation of the start-up is based on the transformation of scientific results into innovations, which generate turnover to pay salaries. However, the start-up does not get an exponential potential growth. It has to generate cash flows to finance its development and even its survival.

\section{These results reveal the paradox of the transformation of S\&T human capital into}

financial capital: Star scientists transform their S\&T human capital into financial capital 
through part time involvement in promising start-ups while less famous scientists involved in the management ensure their salaries through their activity within the firm.

The participation of star scientists is supposed to be so valuable that, even if it is partial, investors (shareholders in particular) use it as a quality signal. Such behaviour covers a paradox regarding the agency theory.

The basic argument of contract theory is that the behaviour of the different parties involved - in this case the scientific founders, the financiers and the managers - can be explained and coordinated in the framework of the principal/agent theory. Agency costs include the cost incurred by the shareholder to detect opportunistic behaviour and the costs of incentives for agents to pursue shareholder interests. As P. McNamara (McNamara, 2003) notes, agency costs are very high for shareholders in biotechnology firms because they must not only monitor the firm's managers but also evaluate the relevance of scientific and technical results. The founders' credibility and scientific reputation play an important part in the creation of trust in a context where knowledge asymmetries seem irreducible. Capital investors thus base their decisions on the presence, among the founders, of star scientists to "guarantee" the relevance of their scientific results. The guarantee is nevertheless partial, for the personal commitment of high-level scientists is limited in both financial terms and in employment terms as they retain their positions at university. Moreover, if the risk of a loss of reputation were to constitute a credible threat warranting the monitoring of their behaviour, it would require strong links between the financial and scientific worlds, which do not exist. The only ties that financiers and especially venture capitalists have with the scientific world are as observers: they are not real actors because they have no scientific legitimacy. Hence, the involvement of the most renowned scientists appears to be "cheap talk" (Meidinger et al., 1999), that is, a commitment based only on the goodwill of the person who makes it. This is the first paradox facing the most risky biotech firms. Those 
who have the highest levels of S\&T human capital seem to be able to valorise their human scientific capital economically by minimizing their personal risks, unlike those that have financial capital, even if the transfer of the scientist's patent rights to the firm limits this effect.

Stephan and Levin (Stephan et al., 1996) show that because of the winner-takes-all nature of the scientific race, it is not surprising that financial compensation of university-based scientists is structured in two parts: a guaranteed portion paid regardless of success in research, and a priority-based portion reflecting the value of their contribution to science. One of the paradoxes of the second part of the compensation for star scientists is that it corresponds to a valorisation of that which already exists and not to an incentive to achieve scientifically and to create human capital. Our observations strengthen the argument of Stephan and Levin by showing that the winner-takes-all phenomenon applies not only to the scientific domain and that, for a small number of star scientists, it applies also to the financial context. When star scientists set up a firm, they seem to be doing nothing other than valorising a stock of existing human capital. The creation of firms seems to be an activity of specific valorisation enabling them to build permanent bridges between their university and the firm, and thus to "refill the tube" of scientific results. By contrast, less well-known researchers must simultaneously build up human and financial capital and valorise it. Their activity is more sequential.

This research is still ongoing. Three developments can be done. A larger sample of firms will strengthen our results about the paradox of transforming S\&T human capital into financial capital. It is also necessary to integrate firm trajectories and performances into the analysis. In the five years covered in our analysis period, all 62 firms survived. However, in 2002 we observed two bankruptcies and ten acquisitions. Finally, it would be helpful to have information about the value of the firms to compare the effective richness of the different 
categories of founders and the effectiveness of the transformation of S\&T human capital into financial capital.

\section{References}

Almeida P, Kogut B. 1999. Localization of Knowledge and the Mobility of Engineers in regional Networks. Management Science 45(7): 905-918

Almeida P, Song J, Grant R. 2002. Are Firms Superior to Alliances and Markets? An Empirical Test of Cross-Border Knowledge Building. Organization Science 13: 147-161

Audretsch D, Stephan P. 1999. Knowledge spillovers in Biotechnology : Sources and Incentives. Journal of Evolutionary Economics: 95-107

Autant-Bernard C, Massard N, Mangematin V. 2002. Creation and Growth of high tech SMEs: The role of Local environment. In J Niosi (Ed.), Clusters in high-technology.: Montreal, UQAM

Autio E. 1995. Four types of innovators : a conceptual and empirical study of new, technologybased compagnies as innovators. Entrepreneurship and Regional Development 7: 233-248.

Baum JAC, Calabrese T, Silverman BS. 2000. Don't go it alone: alliance network composition and startups' performance in Canadian Biotechnology. Strategic Management Journal 21:263-294

Bozeman B, Dietz J, Gaughan M. 2001. Scientific and Technical Human Capital: An Alternative Model for Research Evaluation. International Journal of Technology Management 22(8)

Campbell CA. 1992. A Decision Theory Model for Entrepreneurial Acts. Entrepreneurship Theory and Practice 17(1): 21-28

Cohen WM, Nelson RR, Walsh JP. 2002. Links and Impacts: The influence of Public Research on Industrial R\&D. Management Science 48(1): 1-23

Colyvas J, Crow M, Gelijns A, Mazzoleni R, Nelson R, Rosenberg N, Sampat B. 2002. How Do University Inventions Get Into Practice? Management Science 48(1): 61-72

Deeds D-L, Hill CW-L. 1999. An examination of opportunistic action within research alliances: evidence from the biotechnology industry. Journal of Business Venturing 14(2): 141-163

Dietz JS, Chompalov I, Bozeman B, O'Neil-Lane E, Park J. 2000. Using the curriculum vita to study the career paths of scientists and engineers : an exploratory assessment. Scientometrics 49(3): 419-442

Douglas EJ, Shepherd DA. 2002. Self-employment as a career choice: Attitudes, entrepreneurial intentions, and utility maximization. Entrepreneurship Theory and Practice 26(3): 81-91

Ernst\&Young. 2001. Life Sciences in France - 2001- Where creativity meets business. Ernst Young International.: Paris

Kim L. 1997. The dynamics of Samsung's technological Learning in Semiconductors. California Management Review 39: 86-100

Lemarie S, Delooze MA, Mangematin V. 2000. The Development of Biotech SMEs : The role of size, technology and market in France, Germany and United Kingdom. Scientometrics 47(3): $541-560$ 
Liebeskind JP, Oliver AL, Zucker L, Brewer M. 1996. Social Networks, Learning, and Flexibility: Sourcing Scientific Knowledge in New Biotechnology Firms. Organization Science 7(4): $428-442$

Mangematin V, Lemarie S, Boissin JP, Catherine D, Corolleur F, Coronini R, Trommetter M. 2003. Sectoral system of innovation, SMEs development and heterogeneity of trajectories. Research Policy(Forthcoming)

Mangematin V, Nesta L. 1999. What kind of knowledge can a firm absorb? International Journal of Technology Management 37(3-4): 149-172

Maurer I. 2001. Development Processes of Firms' Social Capital: The Cases of two Biotechnology Start-ups. In R Calori (Ed.), EGOS 17th annual conference.: Lyon (FRA)

McNamara P. 2003. Établir un management crédible dans les entreprises high tech déficitaire: le rôle des alliances. In C Thuderoz, V Mangematin (Eds.), Des mondes de confiance. CNRS: Paris

Meidinger C, Robin S, Ruffieux B. 1999. Confiance, réciprocité et "Cheap talk". Revue Economique 50(1): 5-44

Mowery D, Nelson R, Sampat B, Ziedonis A. 2001. The Growth of Patenting and Licensing by U.S. Universities: An Assessment of the Effect of the Bay-Dole Act of 1980. Reseach Policy 30(1): 99-119

Shane S, Stuart T. 2002. Organizational Endowments and the Performance of University Startups. Management Science 48(1): 154-170

Stephan P. 1999. Human Capital and IPO Value of Biotechnology Firms. Working paper

Stephan P, Everahrt S. 1998. The changing rewards to science: The case of biotechnology. Small Business Economics 10(2): 141-151

Swann P, Prevezer M, Stout D (Eds.). 1999. The Dynamics of Industrial Clustering : International Companies in Computing and Biotechnology. Oxford University Press: Oxford

Szulanski G, Jensen RJ. 2001. Facilitating knowledge transfer: an empirical investigation of the role of the template. Wharton school: Reginald H Jones working papers

Winter S. 1987. Knowledge and Competence as Strategic Assets. In DJ Teece (Ed.), The Competitive Challenge: 159-184. Harper \& Row Publishers: New York

Zucker L, Darby M, Brewer B. 1998. Intellectual Human Capital and the Birth of the US Biotechnology Enterprise. American Economic Review 88(1): 290-306

Zucker L, Darby MR. 1999. Star scientist linkages to firms in Apec and European countries : indicators of regional institutional differences affecting competitive advantage. International Journal of Biotechnology 1(1): 119-131

Zucker LG, Darby MR, Armstrong J. 2002. Commercializing Knowledge: University Science, Knowledge Capture, And Firm Performance in Biotechnology. Management Science 48(1): 138153 